\title{
Does oil price uncertainty transmit to the Thai stock market?
}

\author{
Komain Jiranyakul a* \\ a School of Development Economics, National Institute of Development Administration, Thailand \\ *Corresponding author's email address: komain_j@hotmail.com
}

\section{H I G H L I G H T S:}

1. Thailand is an emerging market economy in Southeast Asia that heavily depends on oil imports.

2. The Stock Exchange of Thailand has been the source of equity financing of listed firms from various equity sectors.

3. Fluctuations in world crude oil prices cause volatility transmission from oil to the Stock Exchange of Thailand.

4. The country needs to rely more on renewable energy and natural gas to maintain or improve the production processes of listed firms.

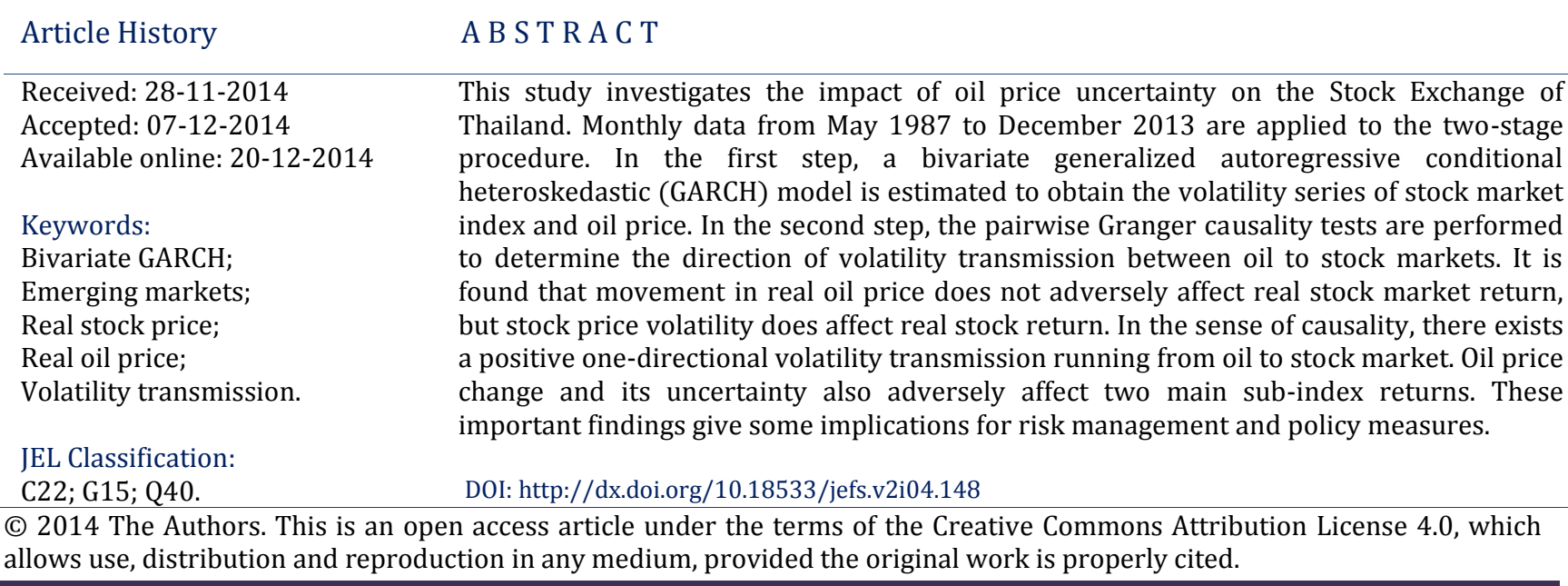

\subsection{Introduction}

The Stock Exchange of Thailand is an emerging stock market in Southeast Asia. It has been the source of equity financing of listed firms from various equity sectors. Capital inflows (portfolio and foreign direct investment) have been in a rising trend since the financial liberalization in the early1990s. The data from the Bank of Thailand show that net capital flow of the country was 1.1 billion US dollars in 1985 and increased to 11.3 in 1991 and 21.5 in 1995. In 2000, three years after the 1997 financial crisis, the net capital flow was -9.8 billion US dollar, but recovered in 2005 and reached the highest point of 24.8 in 2011. Even though the net capital flow is fluctuating, a surge of capital inflow was observed in recent years. Capital inflow to the Thai stock market in terms of portfolio investment has caused foreign investors to play an important role in recent years. Foreign investors can freely invest in government bonds, debentures and stocks. A surge in capital flows to domestic capital market can impose important economic impacts on the Thai economy such as an appreciation in exchange rates, a rising trend in the price level and stock prices. 
Thailand is an oil-importing country that has been relying on imported machinery and equipment. In 1996, one year before the financial crisis, this category of imports accounted for 47.2 percent of total imports, but decreased to 44.3 in 1998 and steadily decreased to 32.6 percent in 2011 and a little recovered thereafter. This can be due to exchange rate fluctuations during the floating regime. As a matter of fact, this category of imports is essential to the production of exported manufacturing goods and is also dependent on imports of crude oil. In Asia, crude oil consumption increased from 11.3 million barrels per day in 1987 to 32.9 million barrels in 2011 (US Energy Information Administration). China and India are the leading demanders in the region. In Southeast Asia, Thailand is the second largest net oil importer behind Singapore. Oil price hike episodes in the world oil markets can exert the impacts on the Thai stock market.

There were several episodes of oil price surges. The data from IEA World Energy Outlook show that the first and second oil price hikes occurred in 1974 and 1978. The world oil price reached its peak in 1981, and declined thereafter. The third oil price surge occurred again in the early1990s due to the Gulf war and gradually declined. After 2002, the rising trend of oil price was observed. Oil price fluctuations caused mainly by these episodes can create real oil price uncertainty that transmits to the stock markets, especially those of oil-importing countries. Fluctuations in stock market index can be caused by various factors. One main factor that cause stock market index to fluctuate can be fluctuations in crude oil price. In the context of volatility transmission, oil price fluctuations caused mainly by the episodes oil price surge can create real oil price uncertainty that transmits to the stock markets, especially those of oil-importing countries. Most studies that focus on volatility transmission from oil to stock markets have been conducted for advanced countries, such as the United States, Japan and Euro area countries. Only few studies have been conducted for developing countries. Therefore, it is worth investigating more on volatility transmission in a developing country.

This paper collects the dataset covering the period from May 1987 to December 2013 to answer the following research questions. Does real oil price Granger cause the stock market index? Can oil price change adversely affect real stock market return and real sub-index returns? Does oil price uncertainty transmit to overall market return and sub-index returns? Newly econometric techniques are used to answer the above questions. If the results show that oil price uncertainty affects stock returns, there should be implications for investors and portfolio managers as well as the government. The implications for Thailand might not be different from other developing economies that are dependent on imports of crude oil.

The paper is organized as the following. The next section presents literature review. The third section describes the data and econometric methodology. The fourth section presents empirical results and implications from the empirical results. The last section concludes.

\section{$2.0 \quad$ Literature review}

Theoretically, real oil price shocks rather than nominal oil price shocks should affect decisions by economic agents in an economy. However, movements in real oil price are caused by both nominal oil price and the price level. If nominal oil price and the price level move together in the same direction, the effect of real and nominal oil prices on macroeconomic variables should be the same. Otherwise, real stock price should be the determinant of economic decision. The effect of oil price shocks on macroeconomic variables has been widely examined.

Recently, the focus is on the response of real stock prices to crude oil price. Jones and Gautam (1996) investigate the relationship between oil and stock markets. They find that the reaction of stock prices in the United States and Canada to oil price shocks depends on the impact of the shocks on real cash flows. However, oil price shocks cause larger changes in stock prices than subsequent changes in real cash flows in the United Kingdom and Japan. Their results are based on the standard cash flows/dividend valuation model. Using monthly data, Sadorsky (1999) finds the evidence showing that oil price volatility affects real stock returns in the United States. Ciner (2001) investigates the relationship between oil prices and the stock market in the United States using daily data and finds the evidence that oil shocks affect stock index returns. In addition, the linkage between oil and stock markets is stronger in the 1990s. Papapetrou (2001) uses a multivariate vector-autoregression to examine the dynamic relationship among oil prices, interest rates, real economic activity and employment in Greece. One of the main findings is that oil price significantly explains stock price movements. Basher and Sadorsky (2006) employ a multifactor model to examine the impact of oil price changes on a large set of emerging stock market returns. The find strong evidence that oil price risk affects stock returns in those economies. Using monthly data, Park and Ratti (2008) examine the impact of oil price shocks on stock markets in the United States and 13 European countries. They find that an increase in real oil price shocks has a significant impact on real stock returns within the following month. The increased volatility of oil prices depresses real stock returns in many European countries, but not in the United States. For Norway, an oil-exporting country, there exists a positive response of real stock return to real oil price shocks. Furthermore, the asymmetric effect of oil price shocks on real stock returns is found in the United States and Norway. Cong et al. (2008) find that oil price shocks do not affect real stock returns of most Chinese stock market indexes, except for the indexes of manufacturing and oil companies. 
Apergis and Miller (2009) investigate the impact of oil price changes on stock market returns in the United States, Japan, Canada, and other five European countries under the vector autoregressive framework. They find that stock market returns do not respond in a large way to oil market shocks.

Narayan and Narayan (2010) use daily data for the period 2000-2008 to investigate the impact of oil prices on Vietnam's stock prices. They find a positive and significant impact of oil prices on stock prices. One of the main findings by Kim and Yang (2011) is that the surge in capital inflows in South Korea, Indonesia, Malaysia, Philippines and Thailand cause a rise in stock prices.

Few studies emphasize the mechanism of return and volatility transmission between oil and stock markets and their sector indices. Malik and Hammoudeh (2007) find that oil price volatility affects the volatility of equity indexes in the Gulf countries. Malik and Ewing (2009) use weekly data during 1992 to 2008 to examine volatility transmission between oil prices and equity sector returns. They employ bivariate GARCH models to estimate the mean and conditional variance simultaneously and find the existence of significant transmission of the United States sector index returns and volatility of oil prices.

Arouri et al. (2011) employ a generalized vector autoregressive-generalized autoregressive conditional heteroskedastic (VAR-GARCH) approach to examine volatility transmission between oil and stock markets in Europe and the United States at sector level using weekly data. Their results show that there is a widespread direct spillover of volatility between oil and stock sector returns. Furthermore, the volatility cross effects run only from oil to stock sectors in Europe while bilateral spillover effects are observed in the United States. Masih et al. (2011) find a negative impact of oil price volatility on real stock return in South Korea.

Jouini (2013) employs the VAR-GARCH procedure to investigate the link between world oil price and stock sectors in Saudi Arabia using weekly data during 2007 to 2011. The results show the existence of return and volatility transmission between oil price and stock sectors.

Awartani and Maghyereh (2013) investigate dynamic spillovers of returns and volatilities between world oil prices and stock market indexes in the Gulf Cooperation Council countries, which comprises Bahrain, Kuwait, Oman, Qatar, Saudi Arabia and the United Arab Emirates. One of their main findings is that there exist net spillovers from oil to stock markets.

\subsection{Materials and methods}

Monthly data of stock market index, consumer price index, the dollar exchange rate, and crude oil price are used in this study. The stock market index series is obtained from the Stock Exchange of Thailand website while consumer price index and the dollar exchange rate series are obtained from the Bank of Thailand. The Brent crude oil price series expressed in dollar per barrel is obtained from Energy Information Administration. The data set covers the period from May 1987 to December $2013^{1}$ with 320 observations. $^{2}$ Real stock price index is calculated by deflating nominal index by consumer price index. Real oil price is calculated by multiplying crude oil price by the dollar exchange rate and deflating by consumer price index. Real stock market return $\left(\mathrm{r}^{\mathrm{SP}}\right)$ and real oil price change $\left(\mathrm{r}^{\mathrm{OP}}\right)$ are the percentage rates of change of real stock market index and real crude oil price. The plots of two time series data are shown in Figure 1 ( $a$ and b). Both of them fluctuate regularly with the spike in the early 1990s for real oil price series resulting from 1991 Gulf War. These figures (1a and 1b) could exhibit multiple structural breaks. However, the series are stationary as reported in Table 1.

\begin{tabular}{|c|c|c|c|c|}
\hline \multicolumn{5}{|c|}{ Table 01: Unit root test results, 1987M5-2013M12 } \\
\hline & $\begin{array}{l}\text { ADF test with } \\
\text { constant }\end{array}$ & $\begin{array}{l}\text { ADF test with trend } \\
\text { and constant }\end{array}$ & PP test with constant & $\begin{array}{l}\text { PP test with trend } \\
\text { and constant }\end{array}$ \\
\hline \multirow[t]{2}{*}{$\mathrm{rSP}^{\mathrm{SP}}$} & $-16.822[0]$ & $-16.795[0]$ & $-16.825[11]$ & $-10.643[11]$ \\
\hline & $(0.000)^{* * *}$ & $(0.000)^{* * *}$ & $(0.000)^{* * *}$ & $(0.000)^{* * *}$ \\
\hline \multirow[t]{2}{*}{$\mathrm{rOP}$} & $-6.266[12]$ & $-6.270[12]$ & $-13.434[16]$ & $-13.430[16]$ \\
\hline & $(0.000)^{* * *}$ & $(0.000)^{* * *}$ & $(0.000)^{* * *}$ & $(0.000)^{* * *}$ \\
\hline \multicolumn{5}{|c|}{$\begin{array}{l}\text { Note: } \mathrm{r}^{\mathrm{SP}} \text { stands for the percentage change in real stock market index (real stock market return), and } \mathrm{r}^{\mathrm{OP}} \text { stands for } \\
\text { the percentage in real oil price. The number is bracket is the optimal lags chosen by Akaike information criterion } \\
\text { (AIC) for ADF tests and is the optimal bandwidths chosen by Newey-West using Bartlett kernel for PP test. The } \\
\text { number in parenthesis is the probability of accepting the null of unit root. }{ }^{* * *} \text { indicates significance at the } 1 \text { percent } \\
\text { level. }\end{array}$} \\
\hline
\end{tabular}

The results of unit root tests using Augmented Dickey-Fuller (ADF) and Phillips-Perron (PP) tests for real stock market return $\left(\mathrm{r}^{\mathrm{SP}}\right)$ and change in real oil price $\left(\mathrm{r}^{\mathrm{OP}}\right)$ are stationary.

\footnotetext{
1 The period is limited by the availability of crude oil price.

${ }^{2}$ In fact, the size and significance of parameters in the conditional variance depend on the data frequency being used. Monthly data set allows for a longer time span and can capture the long-run impact of volatility on other variables.
} 


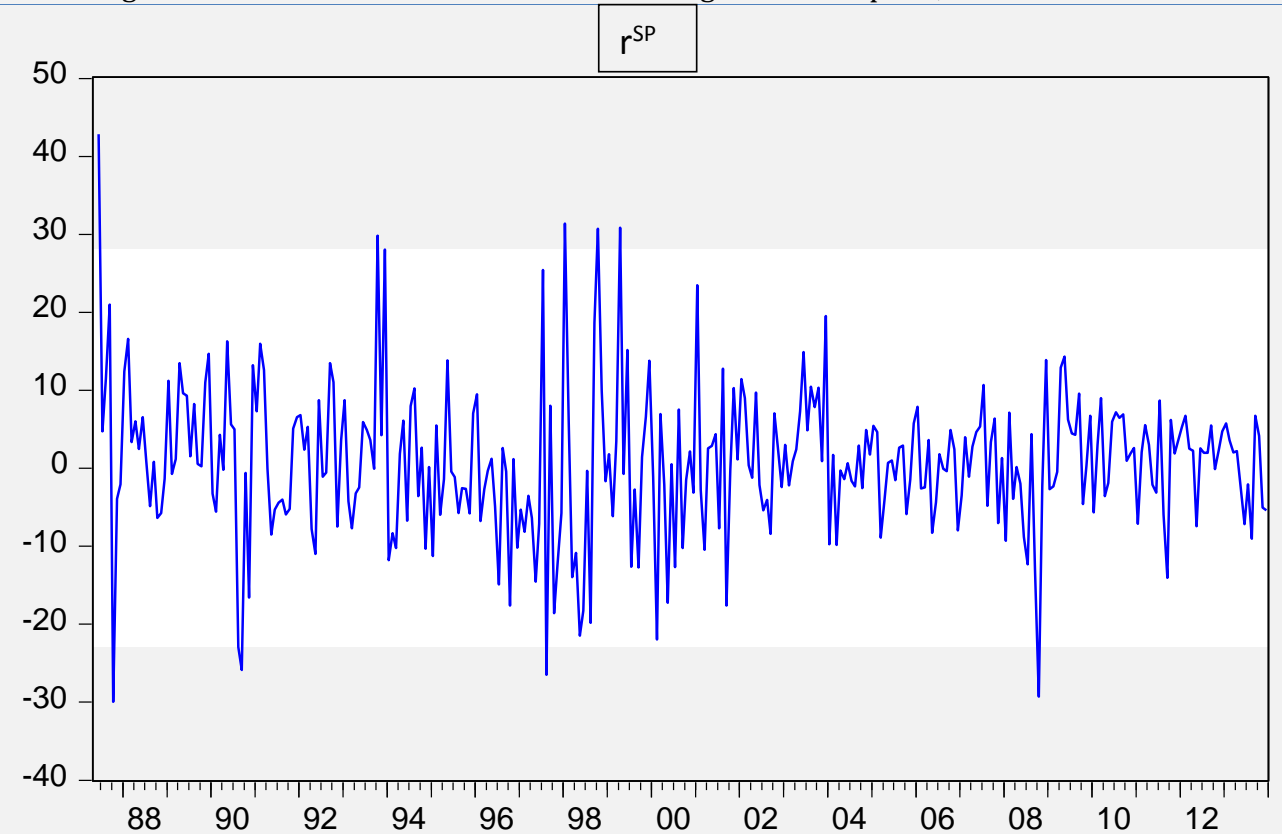

a. Real stock market return

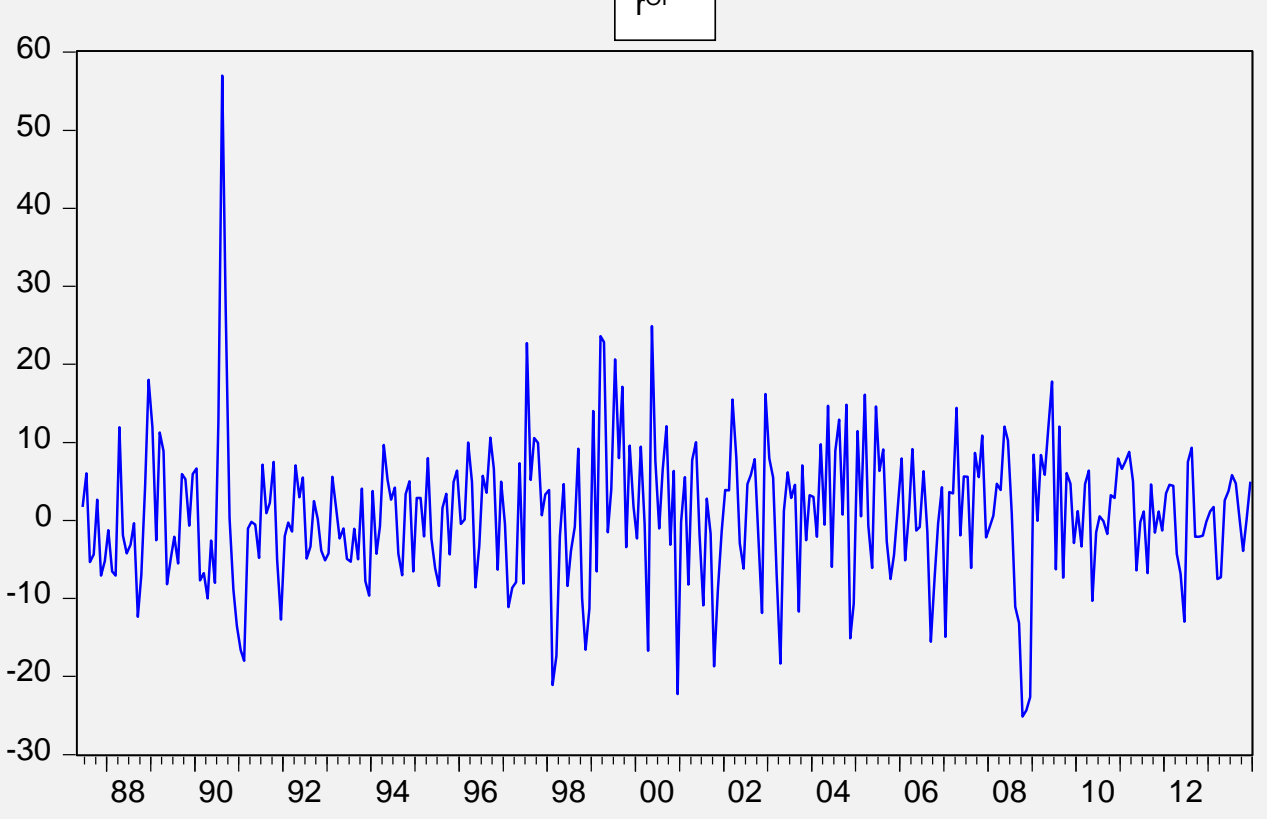

b. Change in real oil price

The stationarity property of the two series enables one to perform the estimation of a bivariate GARCH model.

Summary statistics of real oil movement and real stock return series are reported in Table 2 . The average monthly stock return is 0727 whereas the average monthly oil price rate of change is 0.728 . The Jarque-Bera normality test rejects the null of a normal distribution of both series, indicating that least squares estimation is not suitable.

\begin{tabular}{lcc}
\hline & Table 02: Summary statistics, 1987M5-2013M12 \\
\hline Mean & $\mathrm{r}^{\mathrm{SP}}$ & $\mathrm{r}^{\mathrm{OP}}$ \\
Standard deviation & 0.727 & 0.728 \\
Skewness & 9.524 & 8.963 \\
Kurtosis & 0.273 & 0.654 \\
Jaque-Bera Statistic & 5.351 & 7.745 \\
& 77.152 & 321.973 \\
\hline
\end{tabular}

Note: $\mathrm{r}^{\mathrm{SP}}$ stands for the percentage change in real stock market index (real stock market return), and $\mathrm{r}^{\mathrm{OP}}$ stands for the percentage in real oil price. The number in parenthesis is the probability of accepting the null of normality. 
In an empirical model, some researchers include oil price variable as one of various determinants of stock market index. However, cointegration tests in a bivariate framework often fail to find a long-run equilibrium relationship between crude oil prices and stock prices in emerging stock markets. This might be because of omitted variables in the regression. Testing for causal relationship in a bivariate framework can also capture the relationship between real stock market index and real oil price.

The first attempt is to conduct the test for causal relationship between real oil price and real stock market index in a bivariate framework using the non-causality test proposed by Toda and Yamamoto (1995). This method has significant advantage since prior knowledge whether the variables are cointegrated is unnecessary as long as the order of integration does not exceed the lag length. The variables in the model are tested in their levels. This bivariate vector autoregressive (VAR) model is specified in equations (1) and (2) below. Equation (1) is used to test whether real oil price causes real stock market index while equation (2) is used to test whether real stock market index causes real oil price. The error terms are white noise.

$$
\begin{aligned}
& L R S P_{t}=\alpha_{0}+\sum_{i=1}^{k} \alpha_{i} L R S P_{t-i}+\sum_{j=k+1}^{k+d_{\max }} \alpha_{j} L R S P_{t-j}+\sum_{i=1}^{k} \beta_{i} L R O P_{t-i}+\sum_{j=k+1}^{k+d_{\max }} \beta_{j} L R O P_{t+j}+\varepsilon_{t} \\
& L R O P_{t}=\gamma_{0}+\sum_{i=1}^{k} \gamma_{i} \operatorname{LROP}_{t-i}+\sum_{j=k+1}^{k+d_{\max }} \gamma_{j} L R O P_{t-j}+\sum_{i=1}^{k} \phi_{i} L R S P_{t-i}+\sum_{j=k+1}^{k+d_{\max }} \phi_{j} L R S P_{t+j}+u_{t}
\end{aligned}
$$

Where LRSP is the log of real stock market index, LROP is the log of real oil price.

The testing procedure consists of the following steps: the first step begins with testing for zero restrictions of the coefficients of all lag variables since the extra lagged variables are included in the model. Testing whether the variables in the model cause each other is a test of the joint restriction where all coefficients are zero, the second step determines the optimal lag length (k) using Schwertz information criterion (SIC), the third step estimates a VAR of order $\mathrm{k}^{*}=\mathrm{k}+\mathrm{d}_{\max }$, where $\mathrm{d}_{\max }$ is the maximum anticipated order of integration, and the final step uses the Wald tests for linear or non-linear restrictions whether the series is I(0), I(1) or I(2) according to Rambaldi and Doran (1996). This procedure can prevent biases that may occur when using the standard unit root and cointegration tests.

Another estimation method that can capture the link between crude oil and stock markets is the model of volatility spillovers. The two-step approach is employed in the second attempt to explain the relationship between oil price volatility and the Thai stock market. In the first step, a bivariate generalized autoregressive heteroskedastic model with constant conditional correlation (ccc-GARCH model proposed by Bollerslev (1990) is employed to generate stock and oil price volatilities. In the second step, these generated series along with real stock market return and the rate of change in oil price series employed in the standard Granger (1969) causality test. Pagan (1984) criticizes this procedure because it produces the generated series of volatility or uncertainty. When these generated series are used as regressors in Granger causality test, the model might be misspecified. However, the full information maximum likelihood method that simultaneously tests the impact of volatility in the mean equation can give the same results (see Oteng-Abayie and Doe, 2013). ${ }^{3}$ Furthermore, the main advantage of the two-step procedure is that it provides room for the ability to establish causality between variables. The system equations in a cccGARCH $(1,1)$ model comprises the following five equations.

$$
\begin{aligned}
& r_{t}^{S P}=a_{1,0}+\sum_{i=1}^{p} a_{1, i} r_{t-i}^{S P}+\sum_{i=1}^{p} b_{1, i} r_{t-i}^{O P}+e_{1, t} \\
& h_{t}^{S P}=\mu_{1}+\alpha_{1,1} \varepsilon_{t-1}^{2, S P}+\beta_{1,1} h_{t-1}^{S P} \\
& r_{t}^{O P}=a_{2,0}+\sum_{i=1}^{p} a_{1, i} r_{t-i}^{O P}+e_{2, t} \\
& h_{t}^{O P}=\mu_{2}+\alpha_{2,1} \varepsilon_{t-1}^{2, O P}+\beta_{2,1} h_{t-1}^{O P} \\
& h_{t}^{S P, O P}=\rho_{12}\left(h_{t}^{S P}\right)^{1 / 2}\left(h_{t}^{O P}\right)^{1 / 2}
\end{aligned}
$$

\footnotetext{
3 The possible case indicating the difference of the two procedures is that when the GARCH-in-mean model fails to detect the impact of current period of one variable on current period of another variable does not imply that some of its lags will have no impact at all.
} 
Where $r^{S P}$ is the real stock market return, and $r^{\mathrm{OP}}$ is the movement in real oil price (the rate of change), $\mathrm{h}^{\mathrm{SP}}$ is the conditional variance of real stock market return, $\mathrm{h}^{\mathrm{OP}}$ is the conditional variance of real oil price change, and $\mathrm{h}^{\mathrm{SP}, \mathrm{OP}}$ is the conditional covariance of the two variables. The constant conditional correlation is $\rho_{12}$. The system equations can be estimated simultaneously. The coefficients of ARCH term $\left(\varepsilon^{2} t\right)$ and GARCH term $\left(h_{t}\right)$ as well as the intercept must be non-negative. The sum of these coefficients should be less than one if the conditional variance series will be stationary.

The pairwise Granger causality test is performed in the following equation.

$$
y_{t}=a+\sum_{i=1}^{k} \alpha_{i} y_{t-i}+\sum_{i=1}^{k} \beta_{i} x_{1, t-i}+\sum_{i=1}^{k} \gamma_{i} x_{2, t-i}+\sum_{i=1}^{k} \phi_{i} x_{3, t-i}+u_{t}
$$

Where $\mathrm{y}$ is a dependent variable, and $\mathrm{x}_{1}, \mathrm{x}_{2}$, and $\mathrm{x}_{3}$ are independent variables. If any independent variable causes the dependent variable, there should be at least one significant coefficient of that lagged independent variable. This also indicates that the F-statistic in the standard causality test must show significance for each pair of variables. In the present study, the sequence of variables that will enter into a vector autoregression is $\left\{r^{S P}, r^{\mathrm{OP}}, \mathrm{h}^{\mathrm{SP}}, \mathrm{h}^{\mathrm{OP}}\right\},\left\{\mathrm{r}^{\mathrm{OP}}, \mathrm{r}^{\mathrm{SP}}, \mathrm{h}^{\mathrm{SP}}\right.$, $\left.h^{O P}\right\},\left\{h^{S P}, r^{S P}, r^{O P}, h^{O P}\right\}$, and $\left\{h^{O P}, r^{S P}, r^{O P}, h^{S P}\right\}$. The optimal lag length is determined by AIC. It should be noted that all variables in the test must be stationary. An unrestricted vector autoregressive (VAR) model is used to detect the sign of lagged variables.

\subsection{Results and implications}

The results of Granger non-causality tests are shown in Table 3. In the VAR model, the optimal lag length determined by SIC is two. The anticipated maximum order of integration of all variables is one resulting from the unit root test in Table 1. Thus, the whole lag length is three specified as VAR(3) model. The misspecification tests for serial correlation, normality, and heteroscedasticity in the VAR(3) model are also reported.

\begin{tabular}{lcc}
\hline & Table 03: Results of non-causality test, 1987M5-2013M12 \\
\hline Hypothesis & $\chi^{2}(3)$ & $\mathrm{p}$-value \\
\hline LROP does not cause LRSP & $2.828(-)$ & 0.419 \\
LRSP does not cause LROP & $0.425(-)$ & 0.935 \\
\hline Misspecification tests & Test statistic & 0.210 \\
\hline LM & 5.856 & 0.000 \\
WH & 96.111 & 0.001 \\
JB & 14.173 & \\
\hline Note: LRSP stands for the log of real stock market index, and LROP stands for the log of real oil price. LM is the \\
Lagrange multiplier test for serial correlation up to third order in the residuals, WH is the White heteroskedasticity \\
test of the residuals, and JB is the Jarque-Bera statistic for testing the null hypothesis that the residuals are \\
multivariate normal. The minus sign in parenthesis indicates negative causation.
\end{tabular}

The results in Table 3 show that the null hypotheses that real oil price does not cause real stock market index and that real stock market index does not cause real oil price are accepted. Further tests are conducted to investigate the misspecification of the augmented VAR(3) models used in the analysis. The Lagrange multiplier (LM) test statistic indicates the acceptance of the null hypothesis that there is no serial correlation in the residuals up to the third order of lags. Furthermore the White heteroscedasticity (WH) test shows that the null hypothesis of the presence of autoregressive conditional heteroskedastic (ARCH) effect can be rejected at the 1 percent level of significance. In addition, the Jarque-Bera (JB) statistic indicates that the residuals are not multivariate normal. Therefore, it cannot be concluded that the augmented VAR model is suitable for testing non-causality between the two series.

The bivariate GARCH estimation for the system equations (3) to (7) to obtain the volatility series are reported in Table 4.

The assumption of constant conditional correlation facilitates the simplicity of the system estimation. The model performs quite well in the data set. The mean equation for real stock market return is assumed to be dependent on the lag of real oil price change while the mean equation for real oil price change is assumed to be independent of the lag of real stock market return. ${ }^{4}$ The lags are chosen so that the system equations are free of serial correlation. Panels A and B contain the results of the conditional means and variances for stock market return and oil price change, respectively. 
Table 04: Results from the estimates of a bivariate AR(p)-cccGARCH(1,1) model, 1987M5-2013M12

\begin{tabular}{|c|c|}
\hline \multicolumn{2}{|l|}{ Panel A: Real stock return equation } \\
\hline Conditional mean equation: & $\begin{array}{l}r^{S P_{t}}=0.893+0.085 r^{S P_{t-1}-0.065} r^{O P_{t-1}} \\
(1.747)^{*}(1.403) \quad(-1.273)\end{array}$ \\
\hline Conditional variance equation: & 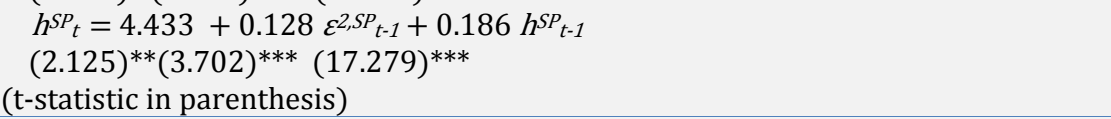 \\
\hline \multicolumn{2}{|c|}{ Panel B: Equation of oil price change } \\
\hline Conditional mean equation: & 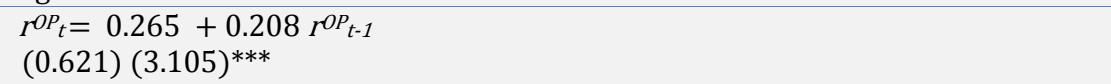 \\
\hline Conditional variance equation: & 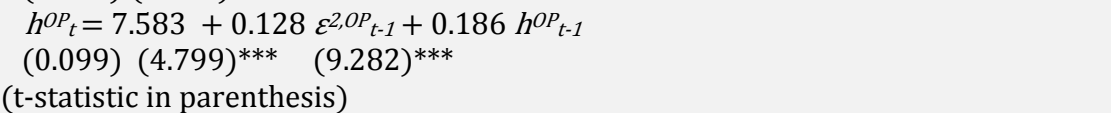 \\
\hline \multicolumn{2}{|c|}{ Panel C: Conditional covariance equation } \\
\hline \multicolumn{2}{|c|}{$\begin{array}{l}h S P_{, O P}=-0.062\left(h^{S P_{t}}\right)^{1 / 2}\left(h^{O P P_{t}}\right)^{1 / 2} \\
\quad(-1.033) \\
\quad(\mathrm{t} \text {-statistic in parenthesis) }\end{array}$} \\
\hline \multicolumn{2}{|c|}{ Panel D: System diagnostic test using residual Portmanteau tests for autocorrelation } \\
\hline & $\begin{array}{l}2(8)=34.242 \\
\quad(0.361) \\
(p-v a l u e \text { in parenthesis) }\end{array}$ \\
\hline $\begin{array}{l}\text { Note: } r^{S P} \text { stands for the percenta } \\
\text { percentage in real oil price, } h^{S P} \\
\text { denote significance at the } 1,5, \text { a }\end{array}$ & $\begin{array}{l}\text { age change in real stock market index (real stock market return), } \mathrm{r}^{\mathrm{OP}} \text { stands for the } \\
\text { stands for stock return volatility, and h }{ }^{\mathrm{OP}} \text { stands for oil price volatility. }{ }^{* *},{ }^{* *} \text {, and } \\
\text { ind } 10 \text { percent, respectively. }\end{array}$ \\
\hline
\end{tabular}

Referring to Panel A, stock market return is not affected by oil price change. In Panel B, Oil price change is affected by its one-period lag. The coefficients in the two conditional variance equations are non-negative. Both conditional variance equations give significant ARCH and GARCH terms ( $\alpha$ and $\beta$ ). The sum of the coefficients of the ARCH and GARCH terms for real stock return is 0.998 whereas the sum of coefficients for real oil price change is 0.939 . These results show that the GARCH variance series as measures of volatility or uncertainty is stationary. The constant conditional correlation in Panel C is -0.062 , which is low and not statistically significant. The system diagnostic test using residual portmanteau test for autocorrelation accepts the null of no autocorrelation as indicated by Q(8) statistic. Therefore, the system equations are free of serial correlation. The volatility series are generated so as to examine their impacts on stock market return and volatility in the standard Granger causality test. The threshold GARCH model proposed by Zakoian (1994) is also estimated, but the asymmetric is not found. Therefore the standard Granger causality test are conducted by relying on the generated variance series from the AR-cccGARCH(1,1) model.

The results of the pairwise Granger causality test are reported in Table 5. The results show some important findings. First, an increase in real oil price seems to cause real stock market return to fall, but this result is not statistically significant. Therefore, there is no evidence that real oil price change can cause a decline in real stock market return. This finding does not support the findings by Ciner (2001) and Papapetrou (2001). Second, stock price volatility negatively affects real stock market return, i.e., an increase in oil price volatility causes stock market return to increase, and vice versa. This confirms the finding by Sadorsky (1999). Third, stock market return does not affect stock price volatility. Fourth, real oil price volatility does not affect real stock market return, which is contradictory to the results of Masih et al. (2011). However, real oil price does affect real stock price volatility. An increase in oil price volatility causes an increase in stock price volatility and vice versa. This is an evidence of volatility spillover in one direction. Finally, a movement in real oil price causes stock price volatility to increase. The results do confirm the finding by Awartani and Maghyereh (2013).

\begin{tabular}{|c|c|c|}
\hline \multicolumn{3}{|c|}{ Table 05: Pairwise Granger causality test results, 1987M5-2013M12 } \\
\hline Hypothesis & F-statistic & $\mathrm{p}$-value \\
\hline roP does not cause rSP & $0.913(-)$ & 0.435 \\
\hline $\mathrm{h}^{\mathrm{SP}}$ does not cause $\mathrm{r}^{\mathrm{SP}}$ & $2.392 *(-)$ & 0.069 \\
\hline rSP does not cause $h^{S P}$ & $0.988(+)$ & 0.399 \\
\hline $\mathrm{h}^{\mathrm{OP}}$ does not cause $\mathrm{rSP}$ & $1.991(+)$ & 0.115 \\
\hline $\mathrm{r}^{\mathrm{OP}}$ does not cause $\mathrm{h}$ SP & $4.126^{* * *}(+)$ & 0.007 \\
\hline $\mathrm{h}^{\mathrm{OP}}$ does not cause $\mathrm{h}^{\mathrm{SP}}$ & $4.792^{* * *}(+)$ & 0.003 \\
\hline $\begin{array}{l}\text { Note: } r^{S P} \text { stands for the } \\
\text { percentage in real oil } \\
\text { lags of } 3 \text { are determine } \\
\text { and - in parenthesis in }\end{array}$ & $\begin{array}{l}\text { x (real stock } 1 \\
d \text { h }{ }^{O P} \text { stands } f \\
\text { e } 1,5 \text {, and } 10\end{array}$ & $\begin{array}{l}\text { rn), rOP stands for the } \\
\text { volatility. The optimal } \\
\text { spectively. The signs + }\end{array}$ \\
\hline
\end{tabular}

The estimate from VAR with the optimal lags of 3 gives the impulse responses of variables as shown in Figure 2. The information contained in the VAR (3) can be represented by graphs of the impulse response functions. The impulse responses illustrate the dynamic response path of a variable due to a one-period standard deviation shock to 
another variable. The graphs give some further evidence on the pattern of linkages between oil and stock markets. All variables of interest are shown in the figure, i. e., oil price movement and its volatility that affect stock return and its volatility. Referring to Figures $1 \mathrm{a}$ and $1 \mathrm{~b}$, the response of real stock return to oil price shock is negative but lasts for 3 months only while the response of real stock return to oil price volatility is also negative but lasts for only 4 months. The response of stock price volatility to oil price shock in Figure 1c is negative and lasts only 2 months whereas the response of real stock return to oil price volatility shock (Figure 1d) is negative but becomes positive within 4 months and dissipates within 9 months. In Figure 1e, the response of oil price volatility to oil price shock is positive and lasts for 10 months. The positive response of stock price volatility to oil price volatility shock is positive and decreases within 3 months, but never dissipates as shown in Figure 1f. The results seem to confirm those from Granger causality tests.

Monthly data for three sub-indices are also available from the Stock Exchange of Thailand website, but at different time periods. The two-step procedure is used to test the impact of real oil price movements on returns and the impact of real oil price volatility on returns and stock price volatility for each sub-index.

For SET50 index comprising 50 stocks of listed companies from various equity sectors, the data are available from September 1995 to December 2013 with 220 observations. The SET100 index comprising 100 stocks of listed companies are available from May 2005 to December 2013 with 104 observations. The market for alternative investment (MAI) index comprising small and medium sized companies are available from September 2002 to December 2013 with 136 observations.

Figure 02: Impulse responses from VAR estimate

Response to Cholesky One S.D. Innovations ? 2 S.E.
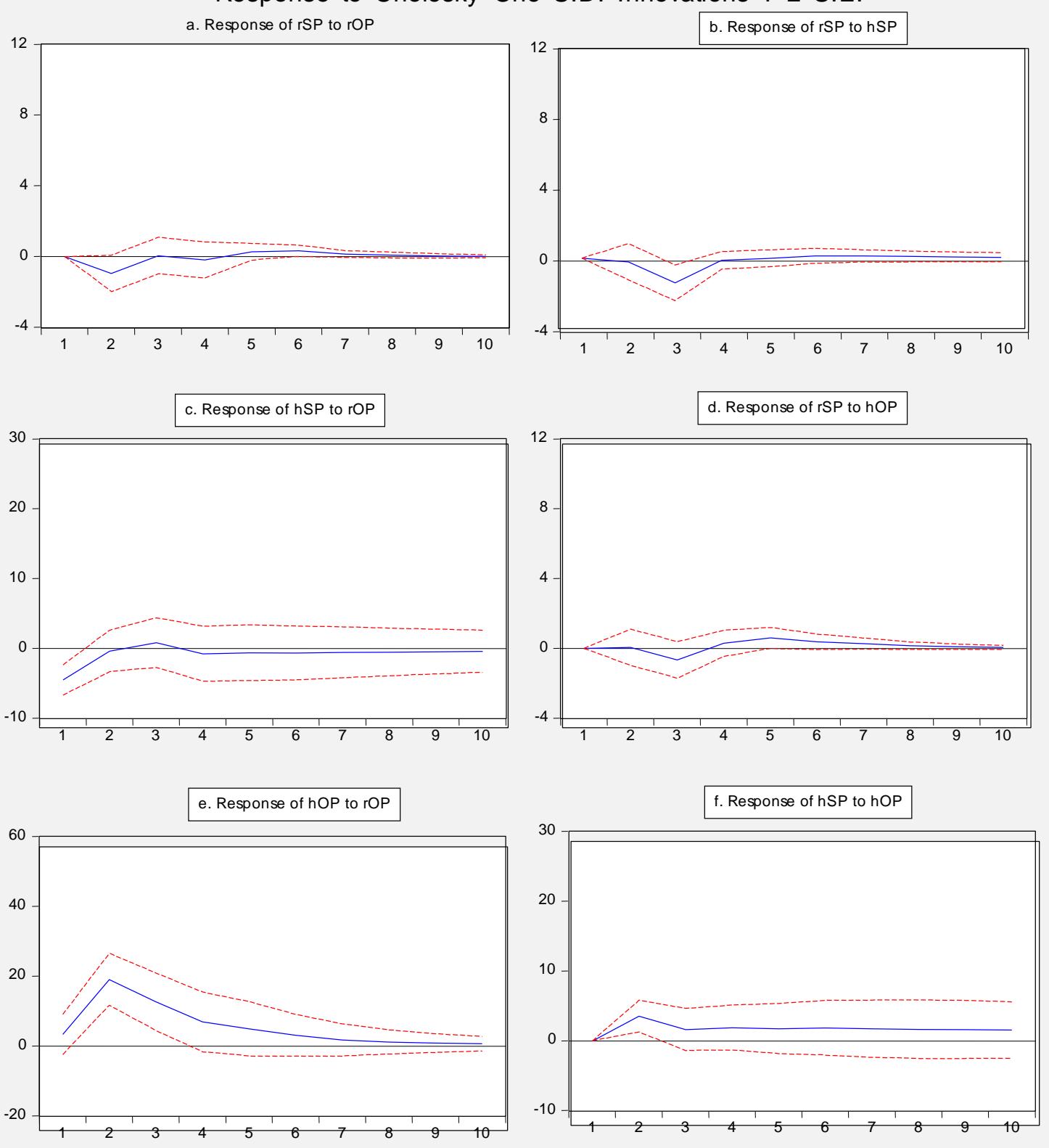
The results from pairwise Granger causality test for the rate of change of these indices that are linked to the rate of change in real oil price and its volatility generated from a specified bivariate GARCH model similar to the estimated model in Section 3.1 are reported in Table 6.

The results in Panel A of Table 6 show that oil price shock does not affect the index return for SET50, but oil price uncertainty does adversely affect this index return. In Panel B, oil price shock significantly causes the index return of SET100 to decrease, but oil price uncertainty does not negatively affect the index return. In Panel C, the impact is different. Oil price shock and oil price volatility does not affect in the index return. For oil price uncertainty transmission, there seems to be no transmission to sub-index volatility at all. As a matter of fact, the MAI index comprises stocks of small and medium sized companies. These companies use less oil for production and thus are not affected by oil price shock and its volatility. On the contrary SET 50 index is the market capitalization weighted index and is the subset of the SET index. This index is calculated from stock prices of enterprises with large market capitalization in main equity sectors, such as energy and utilities, telecommunication, banking and finance, agro and food industry, and properties. The SET 100 index is calculated from stock prices of 50 more enterprises.

\begin{tabular}{|c|c|c|}
\hline \multicolumn{3}{|c|}{ Table 06: Pairwise Granger causality test results for sub-indices } \\
\hline \multicolumn{3}{|c|}{ A. SET 50 index, 1995M8-2013M12 } \\
\hline Hypothesis & F-statistic & p-value \\
\hline $\mathrm{r}^{\mathrm{OP}}$ does not cause $\mathrm{rSP}^{\mathrm{SP}}$ & $0.117(-)$ & 0.977 \\
\hline $\mathrm{h}^{\mathrm{OP}}$ does not cause $\mathrm{rPP}^{\mathrm{SP}}$ & $2.112^{*}(-)$ & 0.081 \\
\hline $\mathrm{h}^{\mathrm{OP}}$ does not cause $\mathrm{h}^{\mathrm{SP}}$ & $0.872(+)$ & 0.481 \\
\hline \multicolumn{3}{|l|}{ B. SET 100 index, 2005M5-2013M12 } \\
\hline Hypothesis & F-statistic & p-value \\
\hline $\mathrm{r}^{\mathrm{OP}}$ does not cause $\mathrm{rSP}^{\mathrm{SP}}$ & $6.164^{* * *}(-)$ & 0.001 \\
\hline $\mathrm{h}^{\mathrm{OP}}$ does not cause $\mathrm{r}^{\mathrm{SP}}$ & $0.839(-)$ & 0.476 \\
\hline $\mathrm{h}^{\mathrm{OP}}$ does not cause $\mathrm{h}^{\mathrm{SP}}$ & $0.258(+)$ & 0.784 \\
\hline \multicolumn{3}{|l|}{ C. MAI index, 2002M9-2013M12 } \\
\hline Hypothesis & F-statistic & p-value \\
\hline rOP does not cause $\mathrm{r}^{\mathrm{SP}}$ & $0.766(-)$ & 0.467 \\
\hline $\mathrm{h}^{\mathrm{OP}}$ does not cause $\mathrm{rSP}^{\mathrm{SP}}$ & $0.034(-)$ & 0.967 \\
\hline $\mathrm{h}^{\mathrm{OP}}$ does not cause $\mathrm{h}^{\mathrm{SP}}$ & $0.126(+)$ & 0.806 \\
\hline $\begin{array}{l}\text { Note: } r^{S P} \text { stands for the percentage cl} \\
\text { index return volatility, and hOP stand } \\
\text { denote significance at the } 1,5 \text {, and } 1 \\
\text { negative causality. }\end{array}$ & $\begin{array}{l}\mathrm{r}^{\mathrm{OP}} \text { stands fo } \\
\text { ity. The optin } \\
\text { ely. The signs }\end{array}$ & $\begin{array}{l}\text { real oil price, } \mathrm{h}^{\mathrm{SP}} \text { stands for } \\
\text { nined by AIC. } * * *, * *, \text { and }{ }^{*} \\
\text { hesis indicate positive and }\end{array}$ \\
\hline
\end{tabular}

Therefore, the two index returns are more prone to oil price movements and uncertainty. In addition, the SET 50 and SET 100 indices are constructed to accommodate the issuing futures and options. Therefore, portfolio managers should be aware of the impact of oil price shock and its uncertainty on these sub-indices when they rely on passive portfolio management. For active portfolio managers, it should be necessary to use options as a hedge against risk so as to reduce a portfolio risk when that portfolio return tends to fall due to oil price uncertainty. The government can also impose some measures such as encouraging firms to improve energy efficiency and finding alternative fuels (renewable energy and natural gas). These measures can prevent large fluctuations in listed firms' profitability resulting from oil price uncertainty, which in turn can adversely affect the stock market.

\subsection{Conclusion}

In this study, the impact of oil price volatility on the Thai stock market is investigated. The monthly data used in this study are real stock market return and oil price. The period covers May 1987 to December 2013. The estimation method used is the two stage approach, which comprises the estimation of the ccc-bivariate GARCH(1,1) model to generate volatility series and the use of standard Granger causality test to determine the directions of causation. One of the main findings in this study is that there exists volatility transmission from oil to domestic stock market. For sub-indices, there is no impact of oil price uncertainty on stock price volatility, but oil price movement and its volatility adversely affect two main sub-index returns. Since the SET50 index comprises 50 blue-chip stocks from main equity sectors, index fund managers should realize that a fall in this sub-index return can be caused by the impact of real oil price uncertainty.

The evidence that oil price shocks and oil price volatility that cause an increase in volatility of the stock market and causes a decrease in sub-index returns gives some implications. For risk management, portfolio managers should be aware of the impact of increasing portfolio risk caused by oil price shocks and volatility. They should diversify well enough to reduce their portfolio risk. For policy implications, the government can also impose some measures such as encouraging firms to improve energy efficiency and finding more renewable energy and natural gas to maintain or improve the production processes of listed enterprises in the stock market. 


\section{References}

Arouri, M. E. H., Jouini, J., Ngugen, D. K., 2011. Volatility spillovers between oil prices and stock sector returns: implications for portfolio management. Journal of International money and finance, 30(7): 1387-1405.

Awartani, B., Maghyereh, A. I., 2013. Dynamic spillovers between oil and stock markets in the Gulf Cooperation Council countries. Energy Economics, 36(C): 28-42.

Apergis, N., Miller, S. M., 2009. Do structural oil-market shocks affect stock prices? Energy Economics, 31(4): 569575.

Basher, S. A., Sadorsky, P., 2006. Oil price risk and emerging stock markets. Global Finance Journal, 17(2): 224-251.

Bollerslev, T., 1990. Modelling the coherence in short-run nominal exchange rates: a multivariate generalized ARCH model. Review of Economics and Statistics, 73(3): 498-505.

Ciner, C., 2001. Energy shocks and financial markets: nonlinear linkages. Studies in Nonlinear Dynamics and Econometrics, 5(3): 203-212.

Cong, R-G., Wei, Y-M., Jiao, J-L., Fan, Y., 2008. Relationship between oil price shocks and stock market: an empirical analysis from China. Energy Policy, 36(9): 3544-3553.

Granger, C. W. J., 1969. Investigating causal relations by econometric models and cross spectral methods. Econometrica, 37(3): 424-438.

Jones, C. M., Gautam, K., 1996. Oil and the stock markets. Journal of Finance, 51(2): 463-491.

Jouini, J., 2013. Return and volatility interaction between oil prices and stock markets in Saudi Arabia. Journal of Policy Modeling, 35(6): 1124-1144.

Kim, S., Yang, D.Y. 2011. The impact of capital inflows on asset prices in emerging Asian economies: is too much money chasing too little goods? Open Economies Review, 22(2): 293-315.

Malik, F., Ewing, B. T., 2009. Volatility transmission between oil prices and equity sector returns. International Review of Financial Analysis, 18(1): 95-100.

Malik, F., Hammoudeh, S., 2007. Shock and volatility transmission in the oil, US and Gulf equity markets. International Review of Economics and Finance, 16(3): 357-368.

Masih, R., Peters, S., De Mello, L., 2011. Oil price volatility and stock price fluctuations in an emerging market: evidence from South Korea. Energy Economics, 33(5): 975-986.

Narayan, P. K., Narayan, S., 2010. Modelling the impact of oil prices on Vietnam's stock prices. Applied Energy, 87(1): 356-361.

Oten-Abayie, E. F., Doe, S. K., 2013. Inflation and inflation uncertainty in Ghana. E3 Journal of Business Management and Economics, 4(12): 259-266.

Pagan, A., 1984. Econometric Issues in the analysis of regressions with generated regressors. International Economic Review, 25(2): 221-247.

Papapetrou, E., 2001. Oil price shocks, stock market, economic activity and employment in Greece. Energy Economics, 23 (5): 511-532.

Park, J., Ratti, R. A., 2008. Oil price shocks and stock markets in the US and 13 European countries, Energy Economics, 30(5): 2587-2608.

Rambaldi, A. N., Doran, H. E., 1996. Testing for Granger non-causality in cointegrated system made easy. Working papers in Econometrics and Applied Statistc, 88, University of New England.

Sadorsky, P., 1999. Oil price shocks and stock market activity. Energy Economics, 21(5): 449-469.

Toda, H. Y., Yamamoto, T., 1995. Statistical inferences in vector autoregressions with possibly integrated process. Journal of Econometrics, 66(1/2): 225-250.

Zakoian, J. M., 1994. Threshold heteroskedastic models. Journal of Economic Dynamic and control, 18(5): 931-955. 